\title{
トリクロルメチル-\&-トリアジンと脂肪族 アミンのジ置換反応
}

\section{2-アルキル-4,6-非対称ビス（アルキルアミノ）-S-トリアジンの合成†}

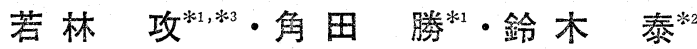 \\ Diamination Reactions of Trichloromethyl-s-triazines with Aliphatic Amines. \\ Syntheses of 2-alkyl-4, 6-unsym. bis (alkylamino)--s-triazines. \\ Studies on $s$-Triazines. V.
}

Ko Wakabayashi ${ }^{* 1}{ }^{* 3}$, Masaru Tsunoda ${ }^{* 1}$ and Yasushi SuzukI ${ }^{* 2}$

\begin{abstract}
A series of 2-alkyl-4,6-unsym. diamino-s-triazines has been synthesized in order to determine the effect on nitrification inhibitory and herbicidal activities of introducing two different amino groups on alkyl-s-triazines ring. The synthetic method involves the reaction of 2 -alkyl-4,6-bis(trichloromethyl)-s-triazines with an aliphatic amine or ammonia to give 2-alkyl-4-alkylamino (or amino)-6-trichloromethyl-s-triazines, which are then condensed with another amine or ammonia. In the preparation of 2-alkyl-4-alkylamino-6-amino-s-triazines, the use of dimethylformamide as solvent gave good results.
\end{abstract}

概 要

著者らは，先報において 2-アルキルー4, 6-ビス（トリ クロルメチル)-s-トリアジン (1) からの 2-アルキル-4, 5-対称ビス（アルキルアミノ)-s-トリアジンの合成に ついて報告したが，その後検討の結果 $s$-トリアジン (1)

† $s$-トリアジンの研究 (第 4 報) : 有合化 28252 (1970)

*1 三菱化成工業 $\mathrm{KK}$ 商品研究所

1 Market Development Research Laboratory, Mitsubishi Chemical Industries Ltd. 三菱化成工業 $K K$ 本社染薬事業部 (1)

*2 Mitsubishi Chemical Industries Ltd.

*3 東京大学学位請求論文の一部より
にアミン類を遂時的に反応させることにより，2-アルキ ル-4, 6-非対称ビス（アルキルアミノ）-S-トリアジン （3）が容易に得られることが判明した。この反応の中間 体 (2)の合成については，第 3 報 ${ }^{1)}$ において報告した。

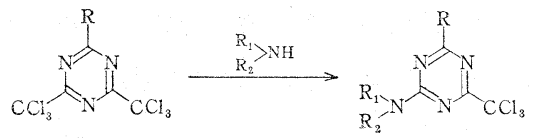

(1)

(2)

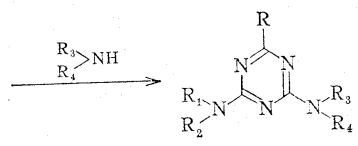

(3)

$\left(\mathrm{R}, \mathrm{R}_{1}\right.$ 执よび $\mathrm{R}_{3}$ 出アルキル基を， $\mathrm{R}_{2}$ および $\mathrm{R}_{4}$ は水素またはア ルキル基を示す）

また 2-アルキル-4-アルキルアミノー6-アミノーงートリア ジンの合成についても少しく検討を行なったので，得ら 
れた結果を合せて報告する。

\section{緒 言}

sートリアジン (3) と 2-アルキル-4, 6-対称ビス（ア ルキルアミノ)-sートリアジンの生物活性を比較検討す るために， -トリアジン (3) の合成が要望された。この 型の $s$-トリアジンの合成については, 従来下記の 2 方 法が知られていた。

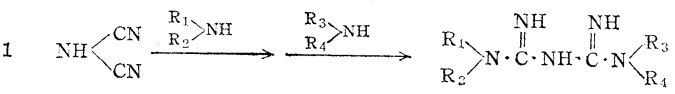

2
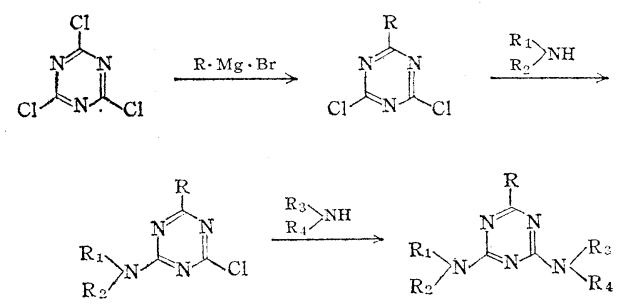

$\left(\mathrm{R}, \mathrm{R}_{1}\right.$ および $\mathrm{R}_{3}$ はアルキル基を， $\mathrm{R}_{2}$ および $\mathrm{R}_{4}$ は水素またはアル キル基を示す)

第 4 報においても述べたが，第 1 法 $^{2}$ では原料となる ジシアノアミン ${ }^{3)}\left(\mathrm{NH}_{\backslash} \mathrm{CN}\right)$ 代高価でかつ合成しにくい 点で，また第 2 法 ${ }^{4}$ ではグリニャール5) 反応が要求され る点に問題があった。このため著者らは，s-トリアシ ン(1)のモノアミノ置換体 (2) を, さらにアミノ化する 検討を行なったところ, 目的物 $s$-トリアジン (3) が好 收率で得られることが判明した。また $s$-トリアジン (2)

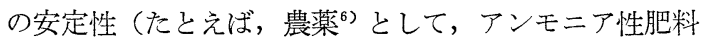
と混用する場合など。）を検討するために，アンモニア との反応を試みたが，その結果二三の 2-アルキル-4-ア ルキルアミノー6ーアミノーงートリアジンを合成すること ができた。以下合せて報告することとする*1)。

\section{結果と考察}

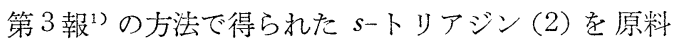
とし，これに過剩の脂肪族アミン (4) を加えると， $s$ トリアジン核に 2 つ異なったアミノ基の付いた $s$-ト リアジン (3) が収率よく得られる。大部分の (4) は液体 で, これを無溶媒あるいは溶媒（水，アルコール，ジメ

*1） 2-アリール-4-アミノ（またはアルキルアミノ）-6-トリクロルメチル ーงートリアジンは，これらと同じ条件下ではアミン類と反応しなかっ た。<smiles>[R]Nc1nc([R])nc(C(Cl)(Cl)Cl)n1</smiles>

(2)

$\left(2 \mathrm{a}: \mathrm{R}=\mathrm{CCl}_{3}\right)$

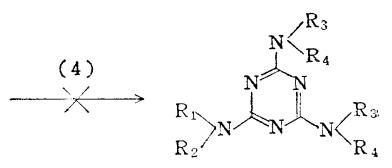

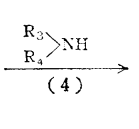

$\mathrm{R}_{2}>\mathrm{N} / \mathrm{N}>\mathrm{N}_{\mathrm{R}}$

(3) $\left(3 \mathrm{a}: \mathrm{R}=\mathrm{CCl}_{3}\right)$

(5)

チルホルムアミドなど) 存在下で， $s$-トリアジン (2) の上に加えると発熱が起り，クロロホルム臭がして反応 の進行がわかる。ほとんど総ての タートリアジン (3) ほ 常温で固体であり，反応の進行とともに系外に，良い純 度で析出してくるが，エタノールなどにより再結晶する のが好ましい。また対称型の $s$-トリアジン (3) は，す でに第 4 報に報告したごとく，2 倍モル以上の (4)を $s$ トリアジン (1) と反応させることにより得られるが， งートリアジン (2) の上に同一アミンを加えることによっ ても得られる。つまり, 第 4 報で得られた2-アルキル -4,6-ビス (アルキルアミノ)-s-トリアジンは，一たん sートリアジン (2) を経てから生成されたものである。 (2a) $\left(\mathrm{R}=\mathrm{CCl}_{3}\right)$ の場合, 過剩の（4) を加えても, (3a) が生成されるにとどまり，それ以上の反応の進行一一 なわちメラミン(5) の生成は見られない。詳細は不明で あるが，(3a）の $\mathrm{CCl}_{3}$ による電子吸引性亡（5)の $\mathrm{N}_{\mathrm{R}_{4}}^{\mathrm{R}_{3}}$ による電子供与性に基づく $s$-トリアジン核の安定性, 換言すれば分子全体の安定性のちがい（安定性：(3a)> (5)）により反応は (3a) にとどまるものと考えられる。

(2b) $\left(\mathrm{R}=\mathrm{CH}_{3}, \mathrm{R}_{1}=\mathrm{C}_{2} \mathrm{H}_{5}, \mathrm{R}_{2}=\mathrm{H}\right)$ 乙 (4a) $\left(\mathrm{R}_{3}=n-\mathrm{C}_{3} \mathrm{H}_{7}\right.$, $\left.\mathrm{R}_{4}=\mathrm{H}\right)$ とから，(3b) ( $\mathrm{R}=\mathrm{CH}_{3}, \mathrm{R}_{1}=\mathrm{C}_{2} \mathrm{H}_{5}, \mathrm{R}_{3}=n-\mathrm{C}_{3} \mathrm{H}_{7}, \mathrm{R}_{2}=$ $\left.\mathrm{R}_{4}=\mathrm{H}\right)$ の生成されたことを以下に述べる。

Beilstein Test で，(3b) はハロゲンを含まないこと が定性的にわかるが，I.R. でも（2b）にみられる 680 $\mathrm{cm}^{-1}$ および $758 \mathrm{~cm}^{-1}(\nu \mathrm{C}-\mathrm{Cl})$ の吸収が ( $\left.3 \mathrm{~b}\right)$ では消 失している。N.M.R. では， $\tau 9.06,8.80,8.47,7.75$, 6.60，4.10４.60 にピークがあり，それぞれ $\mathrm{CH}_{3} \cdot \mathrm{CH}_{2}$ ・ $\mathrm{CH}_{2} \cdot \mathrm{NH}, \mathrm{CH}_{3} \cdot \mathrm{CH}_{2} \cdot \mathrm{NH}, \mathrm{CH}_{3} \cdot \mathrm{CH}_{2} \cdot \mathrm{CH}_{2} \cdot \mathrm{NH}, \mathrm{CH}_{3}$, $\mathrm{CH}_{3} \cdot \mathrm{CH}_{2} \cdot \mathrm{NH}+\mathrm{CH}_{3} \cdot \mathrm{CH}_{2} \cdot \mathrm{CH}_{2} \cdot \mathrm{NH}, \mathrm{CH}_{3} \cdot \mathrm{CH}_{2} \cdot \mathrm{NH}+$ $\mathrm{CH}_{3} \cdot \mathrm{CH}_{2} \cdot \mathrm{CH}_{2} \cdot \mathrm{NH}$ に帰属することができる(表 1 参照)

Mass スペクトルは， m/e 195 に分子量ピーク $\left(\mathrm{M}^{+}\right)$ が見られ，その他主なるフラグメントピークとして， $\mathrm{m} / \mathrm{e} 180\left(\mathrm{M}^{+}-\mathrm{CH}_{3}\right), 166\left(\mathrm{M}^{+}-\mathrm{C}_{2} \mathrm{H}_{5}\right), 152\left(\mathrm{M}^{+}-\mathrm{C}_{3} \mathrm{H}_{7}\right)$ などが存在する。U.V.は，(2b)の $\lambda_{\max }^{\mathrm{CH}_{3} \mathrm{OH}} 238 \mathrm{~m} \mu$ ( $\varepsilon$ 


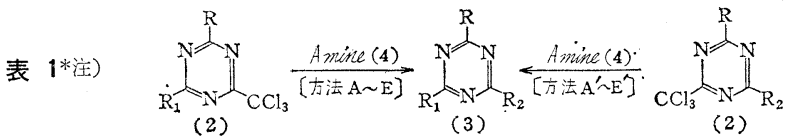

\begin{tabular}{|c|c|c|c|c|c|c|c|}
\hline $\mathrm{R}$ & $\mathrm{R}_{1}$ & $\mathrm{R}_{2}$ & $\underset{\left({ }^{\circ} \mathrm{C}\right)}{\mathrm{Mp}{ }^{* 11}}$ & $\lambda_{\max }^{\mathrm{CH}_{3} \mathrm{OH}}$ & $\left|\begin{array}{c}\text { I.R. } * 2) \\
\mathrm{cm}^{-1}\end{array}\right|$ & $\begin{array}{l}\text { N.M.R.*3) } \\
\tau\left(\mathrm{CDC} 1_{3}\right)\end{array}$ & 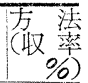 \\
\hline $\mathrm{CH}_{3}$ & $\mathrm{CH}_{3} \cdot \mathrm{NH}$ & $\mathrm{C}_{2} \mathrm{H}_{5} \cdot \mathrm{NH}$ & 181 & $\begin{array}{ll}231 & (9,800) \\
264 & (3,500)\end{array}$ & 1555 & $\begin{array}{ll}8.80\left(\mathrm{t}, 3 \mathrm{H}, \mathrm{CH}_{3}\right) & 7.75\left(\mathrm{~s}, 3 \mathrm{H}, \mathrm{CH}_{3}-\mathrm{R}\right) \\
7.03\left(\mathrm{~b}, 3 \mathrm{H}, \mathrm{CH}_{3}-\mathrm{N}\right) & 6.56\left(\mathrm{qi}, 2 \mathrm{H}, \mathrm{CH}_{2}-\mathrm{N}\right) \\
4.20 \sim 5.00(\mathrm{br}, 2 \mathrm{H}, \mathrm{NH})\end{array}$ & $\begin{array}{l}\mathrm{B}(88) \\
\mathrm{B}^{\prime}(90)\end{array}$ \\
\hline $\mathrm{CH}_{3}$ & $\mathrm{CH}_{3} \cdot \mathrm{NH}$ & $n-\mathrm{C}_{3} \mathrm{H}_{7} \cdot \mathrm{NH}$ & $142 \sim 3$ & $\begin{array}{l}231(10,200) \\
264(3,400)\end{array}$ & 1550 & $\begin{array}{lr}9,05\left(\mathrm{t}, 3 \mathrm{H}, \mathrm{CH}_{3}\right) & 8.38\left(\mathrm{~h}, 2 \mathrm{H}, \mathrm{CH}_{2}\right) \\
7.74\left(\mathrm{~s}, 3 \mathrm{H}, \mathrm{CH}_{3}-\mathrm{R}\right) & 7.03\left(\mathrm{~d}, 3 \mathrm{H}, \mathrm{CH}_{3}-\mathrm{N}\right) \\
6.60\left(\mathrm{q}, 2 \mathrm{H}, \mathrm{CH}_{2}-\mathrm{N}\right) & 3.90 \sim 4.30(\mathrm{br}, 2 \mathrm{H}, \mathrm{NH})\end{array}$ & $\begin{array}{l}\mathrm{A}(85) \\
\mathrm{B}^{\prime}(91)\end{array}$ \\
\hline $\mathrm{CH}_{3}$ & $\mathrm{CH}_{3} \cdot \mathrm{NH}$ & $i s o-\mathrm{C}_{3} \mathrm{H}_{7} \cdot \mathrm{NH}$ & $143 \sim 5$ & $\begin{array}{ll}231 & (10,200) \\
264 & (3,500)\end{array}$ & 1548 & $\begin{array}{lr}8.78\left(\mathrm{~d}, 6 \mathrm{H}, \mathrm{CH}_{3}\right) & 7.75\left(\mathrm{~s}, 3 \mathrm{H}, \mathrm{CH}_{3}-\mathrm{R}\right) \\
7.03\left(\mathrm{~d}, 3 \mathrm{H}, \mathrm{CH}_{3}-\mathrm{N}\right) & 5.75(\mathrm{~m}, \mathrm{H}, \mathrm{CH}-\mathrm{N}) \\
4.20 \sim 4.70(\mathrm{br}, 2 \mathrm{H}, \mathrm{NH}) & \end{array}$ & $\begin{array}{l}\mathrm{A}(90) \\
\mathrm{B}^{\prime}(90)\end{array}$ \\
\hline $\mathrm{CH}_{3}$ & $\mathrm{CH}_{3} \cdot \mathrm{NH}$ & $\mathrm{CH}_{3}\left(\stackrel{\mathrm{a}}{\mathrm{C}} \mathrm{H}_{2}\right)_{2}$ & $140 \sim 1$ & $\begin{array}{ll}231 & (10,500) \\
264 & (3,700)\end{array}$ & 1548 & $\begin{array}{lr}9.06\left(\mathrm{t}, 3 \mathrm{H}, \mathrm{CH}_{3}\right) & 8.20 \sim 8.80(\mathrm{~m}, 4 \mathrm{H}, \mathrm{a}) \\
7.75\left(\mathrm{~s}, 3 \mathrm{H}, \mathrm{CH}_{3}-\mathrm{R}\right) & 7.04\left(\mathrm{~d}, 3 \mathrm{H}, \mathrm{CH}_{3}-\mathrm{N}\right) \\
6.56\left(\mathrm{q}, 2 \mathrm{H}, \mathrm{CH}_{2}-\mathrm{N}\right) & 4.10 \sim 4.60(\mathrm{br}, 2 \mathrm{H}, \mathrm{NH})\end{array}$ & $\begin{array}{l}\mathrm{A}(92) \\
\mathrm{B}^{\prime}(90)\end{array}$ \\
\hline $\mathrm{CH}_{3}$ & $\mathrm{C}_{2} \mathrm{H}_{5} \cdot \mathrm{NH}$ & $\stackrel{\mathrm{a}}{\mathrm{C}} \mathrm{H}_{3} \cdot \mathrm{CH}_{2} \cdot \mathrm{C}$ & $148 \sim 9$ & $\begin{array}{ll}232 & (10,500) \\
264 & (3,800)\end{array}$ & 1548 & $\begin{array}{lr}9.06(\mathrm{t}, 3 \mathrm{H}, \mathrm{a}) & 8.80\left(\mathrm{t}, 3 \mathrm{H}, \mathrm{CH}_{3}\right) \\
8.47\left(\mathrm{~h}, 2 \mathrm{H}, \mathrm{CH}_{2}\right) & 7.75\left(\mathrm{~s}, 3 \mathrm{H}, \mathrm{CH}_{3}-\mathrm{R}\right) \\
6.60\left(\mathrm{~m}, 4 \mathrm{H}, \mathrm{CH}_{2}-\mathrm{N}\right) & 4.10 \sim 4.60(\mathrm{br}, 2 \mathrm{H}, \mathrm{NH})\end{array}$ & $\begin{array}{l}\mathrm{A}(92) \\
\mathrm{B}^{\prime}(83)\end{array}$ \\
\hline $\mathrm{CH}_{3}$ & $\mathrm{C}_{2} \mathrm{H}_{5} \cdot \mathrm{NH}$ & $\begin{array}{l}\mathrm{CH}_{3} \\
\mathrm{CH}_{3}\end{array}>\mathrm{CH} \cdot \mathrm{NH}$ & $150 \sim 3$ & $\begin{array}{l}231(11,800) \\
264(3,500)\end{array}$ & 1548 & $\begin{array}{lr}8.80\left(\mathrm{t}, 3 \mathrm{H}, \mathrm{CH}_{3}\right) & 8.77(\mathrm{~d}, 6 \mathrm{H}, \mathrm{a}) \\
7.75\left(\mathrm{~s}, 3 \mathrm{H}, \mathrm{CH}_{3}-\mathrm{R}\right) & 6.56\left(\mathrm{qi}, 2 \mathrm{H}, \mathrm{CH}_{2}-\mathrm{N}\right) \\
5.74(\mathrm{~m}, \mathrm{H}, \mathrm{CH}-\mathrm{N}) & 4.10 \sim 4.60(\mathrm{br}, 2 \mathrm{H}, \mathrm{NH})\end{array}$ & $\begin{array}{l}\mathrm{A}(90) \\
\mathrm{B}^{\prime}(83)\end{array}$ \\
\hline $\mathrm{CH}_{3}$ & $\mathrm{C}_{2} \mathrm{H}_{5} \cdot \mathrm{NH}$ & $\stackrel{\mathrm{a}}{\mathrm{C}} \mathrm{H}_{3}\left(\stackrel{\mathrm{b}}{\mathrm{CH}_{2}}\right)_{2} \cdot \mathrm{CH}_{2} \cdot \mathrm{NH}$ & $138 \sim 9$ & $\left|\begin{array}{ll}232 & (11,800) \\
264 & (3,500)\end{array}\right|$ & 1550 & $\begin{array}{cr}9.07(\mathrm{t}, 3 \mathrm{H}, \mathrm{a}) & 8.81\left(\mathrm{t}, 3 \mathrm{H}, \mathrm{CH}_{3}\right) \\
8.20 \sim 8.60(\mathrm{~m}, 4 \mathrm{H}, \mathrm{b}) & 7.76\left(\mathrm{~s}, 3 \mathrm{H}, \mathrm{CH}_{3}-\mathrm{R}\right) \\
6.56\left(\mathrm{~m}, 4 \mathrm{H}, \mathrm{CH}_{2}-\mathrm{N}\right) & 3.80 \sim 4.30(\mathrm{br} .2 \mathrm{H}, \mathrm{NH})\end{array}$ & A (93) \\
\hline $\mathrm{CH}_{3}$ & $\mathrm{C}_{2} \mathrm{H}_{5} \cdot \mathrm{NH}$ & $\stackrel{\mathrm{CH}_{3}}{\mathrm{CH}_{3}}>\mathrm{CH} \cdot \mathrm{CH}_{2} \cdot \mathrm{NH}$ & $158 \sim 9$ & $\begin{array}{l}232(11,200) \\
264(3,600)\end{array}$ & 1548 & $\begin{array}{lr}9.05(\mathrm{~d}, 6 \mathrm{H}, \mathrm{a}) & 8.80\left(\mathrm{t}, 3 \mathrm{H}, \mathrm{CH}_{3}\right) \\
7.90 \sim 8.40(\mathrm{~m}, \mathrm{H}, \mathrm{CH}) & 7.76\left(\mathrm{~s}, 3 \mathrm{H}, \mathrm{CH}_{3}-\mathrm{R}\right) \\
6.65\left(\mathrm{~m}, 4 \mathrm{H}, \mathrm{CH}_{2}-\mathrm{N}\right) & 4.50 \sim 5.00(\mathrm{br}, 2 \mathrm{H}, \mathrm{NH})\end{array}$ & $\begin{array}{l}\mathrm{A}(85) \\
\mathrm{B}^{\prime}(96)\end{array}$ \\
\hline $\mathrm{CH}_{3}$ & $\mathrm{C}_{2} \mathrm{H}_{5} \cdot \mathrm{NH}$ & $\mid \begin{array}{c}\mathrm{CH}_{3} \\
\mathrm{CH}_{3} \cdot \underset{\mathrm{b}}{\mathrm{CH}_{2}}\end{array}>\mathrm{CH} \cdot \mathrm{NH}$ & $148 \sim 50$ & 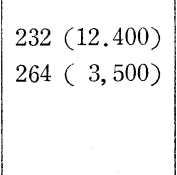 & 1548 & \begin{tabular}{|lr}
$9.07(\mathrm{t}, 3 \mathrm{H}, \mathrm{a})$ & $8.81\left(\mathrm{ca}, \mathrm{t}, 6 \mathrm{H}, \mathrm{CH}_{3}+\mathrm{c}\right)$ \\
$8.48(\mathrm{qi}, 2 \mathrm{H}, \mathrm{b})$ & $7.76\left(\mathrm{~s}, 3 \mathrm{H}, \mathrm{CH}_{3}-\mathrm{R}\right)$ \\
$6.56\left(\mathrm{qi}, 2 \mathrm{H}, \mathrm{CH}_{2}-\mathrm{N}\right)$ & $5.98(\mathrm{~m}, \mathrm{H}, \mathrm{CH}-\mathrm{N})$ \\
$4.30 \sim 4.80(\mathrm{br}, 2 \mathrm{H}, \mathrm{NH})$ &
\end{tabular} & $A(88)$ \\
\hline $\mathrm{CH}_{3}$ & $\mathrm{C}_{2} \mathrm{H}_{5} \cdot \mathrm{NH}$ & $\left(\mathrm{CH}_{3}\right)_{3} \cdot \mathrm{C} \cdot \mathrm{NH}$ & $144 \sim 5$ & $\begin{array}{ll}231 & (13,600) \\
264 & (3,500)\end{array}$ & 1540 & & $C(75)$ \\
\hline $\mathrm{CH}_{3}$ & $\mathrm{C}_{2} \mathrm{H}_{5} \cdot \mathrm{NH}$ & $\stackrel{\mathrm{a}}{\mathrm{C}} \mathrm{H}_{3}\left(\stackrel{\mathrm{b}}{\mathrm{CH}_{2}}\right)_{3} \cdot \mathrm{CH}_{2} \cdot \mathrm{NH}$ & $152 \sim 5$ & $\begin{array}{ll}231 & (13,500) \\
264 & (3,600)\end{array} \mid$ & 1543 & \begin{tabular}{|lr}
$9.10(\mathrm{t}, 3 \mathrm{H}, \mathrm{a})$ & $8.82\left(\mathrm{t}, 3 \mathrm{H}, \mathrm{CH}_{3}\right)$ \\
$8.20 \sim 8.60(\mathrm{~m}, 6 \mathrm{H}, \mathrm{b})$ & $7.76\left(\mathrm{~s}, 3 \mathrm{H}, \mathrm{CH}_{3}-\mathrm{R}\right)$ \\
$6.60\left(\mathrm{~m}, 4 \mathrm{H}, \mathrm{CH}_{2}-\mathrm{N}\right)$ & $3.80 \sim 4.40(\mathrm{br}, 2 \mathrm{H}, \mathrm{NH})$
\end{tabular} & $\begin{array}{l}\mathrm{A}(85) \\
\mathrm{C}(88)\end{array}$ \\
\hline $\mathrm{CH}_{3}$ & $\mathrm{C}_{2} \mathrm{H}_{5} \cdot \mathrm{NH}$ & $\left.\stackrel{\mathrm{a}}{\mathrm{C}} \mathrm{H}_{3} \cdot \stackrel{\mathrm{b}}{\mathrm{C}} \mathrm{CH}_{2}\right)_{4} \cdot \mathrm{CH}_{2} \cdot \mathrm{NH}$ & $120 \sim 1$ & 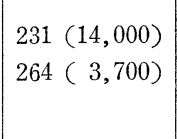 & 1545 & $\begin{array}{lr}9.12(\mathrm{t}, 3 \mathrm{H}, \mathrm{a}) & 8.82\left(\mathrm{t}, 3 \mathrm{H}, \mathrm{CH}_{3}\right) \\
8.30 \sim 8.70(\mathrm{~m}, 8 \mathrm{H}, \mathrm{b}) & 7.76\left(\mathrm{~s}, 3 \mathrm{H}, \mathrm{CH}_{3}-\mathrm{R}\right) \\
6.60\left(\mathrm{~m}, 4 \mathrm{H}, \mathrm{CH}_{2}-\mathrm{N}\right) & 3.80 \sim 4.40(\mathrm{br}, 2 \mathrm{H}, \mathrm{NH})\end{array}$ & $\mathrm{C}(89)$ \\
\hline $\mathrm{CH}_{3}$ & $\mathrm{C}_{2} \mathrm{H}_{5} \cdot \mathrm{NH}$ & $\mid \begin{array}{c}\mathrm{CH}_{3} \cdot\left(\mathrm{CH}_{2}\right)_{4} \\
\mathrm{a} \quad \mathrm{b}\end{array}$ & $115 \sim 8$ & $\begin{array}{l}231(14,200) \\
264(3,500)\end{array}$ & 1543 & & $\begin{array}{l}\mathrm{A}(75) \\
\mathrm{C}(86)\end{array}$ \\
\hline $\mathrm{CH}_{3}$ & $\mathrm{C}_{2} \mathrm{H}_{5} \cdot \mathrm{NH}$ & $\stackrel{\mathrm{a}}{\mathrm{C}} \mathrm{H}_{3} \cdot\left(\mathrm{CH}_{2}\right)_{10} \cdot \mathrm{CH}_{2} \cdot \mathrm{NH}$ & $108 \sim 9$ & $\begin{array}{l}232(16,500) \\
264\end{array}$ & 1545 & \begin{tabular}{|lr}
$9.13(\mathrm{t}, 3 \mathrm{H}, \mathrm{a})$ & $8.82\left(\mathrm{t}, 3 \mathrm{H}, \mathrm{CH}_{\mathrm{s}}\right)$ \\
$8.20 \sim 8.80(\mathrm{~m}, 20 \mathrm{H}, \mathrm{b})$ & $7.76\left(\mathrm{~s}, 3 \mathrm{H}, \mathrm{CH}_{3}-\mathrm{R}\right)$ \\
$6.58\left(\mathrm{~m}, 4 \mathrm{H}, \mathrm{CH}_{2}-\mathrm{N}\right)$ & $3.70 \sim 4.80(\mathrm{br}, 2 \mathrm{H}, \mathrm{NH})$
\end{tabular} & $\begin{array}{l}\mathrm{C}(58) \\
\mathrm{D}(80) \\
\mathrm{E}(73)\end{array}$ \\
\hline
\end{tabular}




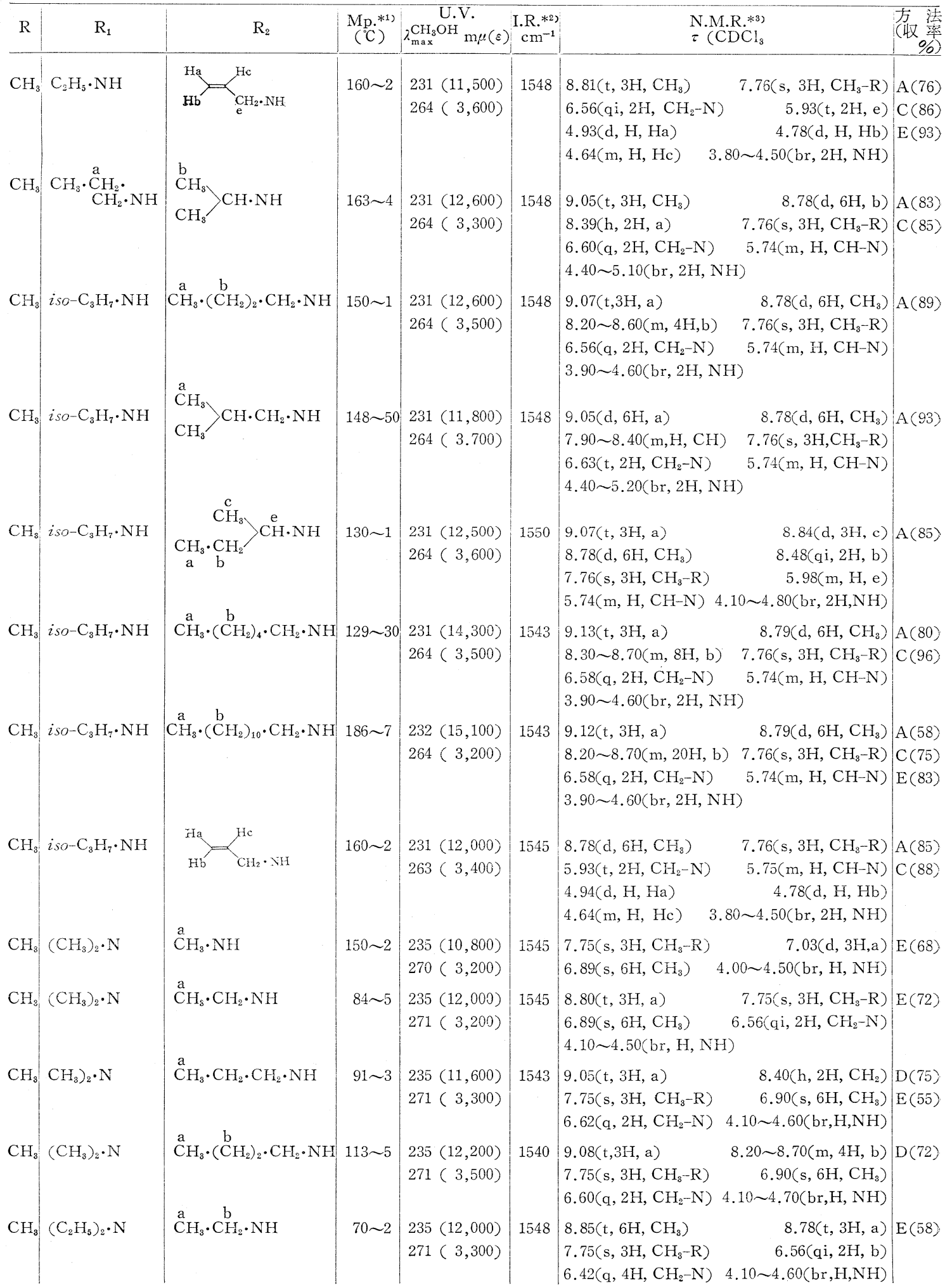




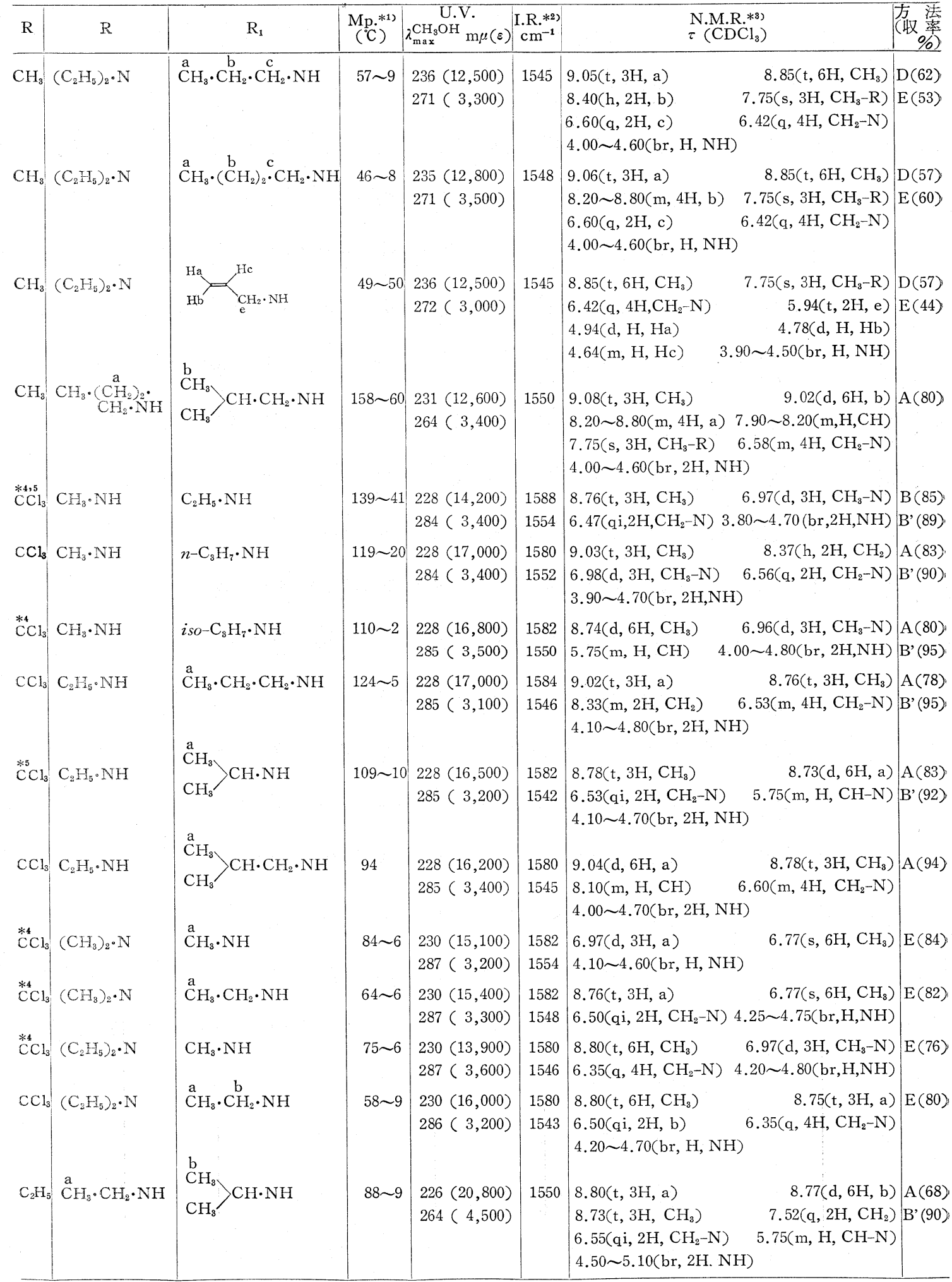


表 2* Amine (4)

(2) (3) (2)

\begin{tabular}{|c|c|c|c|c|c|}
\hline $\mathrm{R}$ & $\mathrm{R}_{1}$ & $\underset{\left({ }^{\circ} \mathrm{C}\right)}{\mathrm{Mp})}$ & $\begin{array}{c}\mathrm{U.V} \\
\lambda_{\max }^{\mathrm{CH}_{3} \mathrm{OH}} \operatorname{m} \mu(\varepsilon)\end{array}$ & $\begin{array}{l}\text { I.R.*2) } \\
\left(\mathrm{cm}^{-1}\right)\end{array}$ & 方 洼)\% \\
\hline $\mathrm{CCl}_{3}$ & $\mathrm{CH}_{3} \mathrm{NH}^{* 3)}$ & $154 \sim 5$ & $\begin{array}{l}219(21,200) \\
280(3,300)\end{array}$ & $\begin{array}{l}1570 \\
1540\end{array}$ & $\begin{array}{l}F(90) \\
G(92)\end{array}$ \\
\hline $\mathrm{CCl}_{3}$ & $\mathrm{C}_{2} \mathrm{H}_{5} \mathrm{NH}$ & $137 \sim 8$ & $\begin{array}{l}218(24,200) \\
280(3,400)\end{array}$ & $\begin{array}{l}1568 \\
1535\end{array}$ & $\begin{array}{l}F(85) \\
G(90)\end{array}$ \\
\hline $\mathrm{CCl}_{3}$ & $n-\mathrm{C}_{3} \mathrm{H}_{7} \mathrm{NH}$ & $118 \sim 9$ & $\begin{array}{l}218(25,100) \\
281(3,200)\end{array}$ & $\begin{array}{l}1568 \\
1535\end{array}$ & $\begin{array}{l}F(86) \\
G(90)\end{array}$ \\
\hline $\mathrm{CCl}_{3}$ & iso- $\mathrm{C}_{3} \mathrm{H}_{7} \mathrm{NH}$ & $151 \sim 2$ & $\begin{array}{l}218(25,100) \\
281(3,100)\end{array}$ & $\begin{array}{l}1568 \\
1535\end{array}$ & $\begin{array}{l}F(88) \\
G(78)\end{array}$ \\
\hline $\mathrm{CCl}_{3}$ & $n-\mathrm{C}_{4} \mathrm{H}_{9} \mathrm{NH}$ & $107 \sim 8$ & $\begin{array}{l}218(26,100) \\
280(3,400)\end{array}$ & $\begin{array}{l}1568 \\
1534\end{array}$ & $\begin{array}{l}F(82) \\
G(85)\end{array}$ \\
\hline $\mathrm{CCl}_{3}$ & iso- $\mathrm{C}_{4} \mathrm{H}_{9} \mathrm{NH}$ & $138 \sim 40$ & $\begin{array}{l}218(25,600) \\
280(3,200)\end{array}$ & $\begin{array}{l}1568 \\
1534\end{array}$ & $\begin{array}{l}F(85) \\
G(87)\end{array}$ \\
\hline $\mathrm{CCl}_{3}$ & sec- $\mathrm{C}_{4} \mathrm{H}_{9} \mathrm{NH}$ & $103 \sim 4$ & $\begin{array}{l}218(24,800) \\
281(3,100)\end{array}$ & $\begin{array}{l}1565 \\
1530\end{array}$ & $\begin{array}{l}F(76) \\
G(80)\end{array}$ \\
\hline $\mathrm{CCl}_{3}$ & $n-\mathrm{C}_{6} \mathrm{H}_{18} \mathrm{NH}$ & $86 \sim 8$ & $\begin{array}{l}218(25,700) \\
281(3,400)\end{array}$ & $\begin{array}{l}1566 \\
1532\end{array}$ & $\begin{array}{l}F(78) \\
G(80)\end{array}$ \\
\hline $\mathrm{CCl}_{3}$ & $-\mathrm{NH}$ & $139 \sim 40$ & $\begin{array}{l}217(28,700) \\
284(3,600)\end{array}$ & $\begin{array}{l}1570 \\
1530\end{array}$ & $\begin{array}{l}F(92) \\
G(86)\end{array}$ \\
\hline $\mathrm{CCl}_{3}$ & $\mathrm{NC} \cdot \mathrm{CH}_{2} \cdot \mathrm{CH}_{2} \cdot \mathrm{NH}$ & $169 \sim 70$ & $\begin{array}{l}217(26,200) \\
279(3,700)\end{array}$ & $\begin{array}{l}1572 \\
1538\end{array}$ & $\begin{array}{l}F(85) \\
G(78)\end{array}$ \\
\hline $\mathrm{CCl}_{3}$ & $\mathrm{HO} \cdot \mathrm{CH}_{2} \cdot \mathrm{CH}_{2} \cdot \mathrm{NH}$ & $160 \sim 1$ & $\begin{array}{l}218(25,900) \\
281(3,400)\end{array}$ & $\begin{array}{l}1578 \\
1535\end{array}$ & $F(68)$ \\
\hline $\mathrm{CCl}_{3}$ & $\begin{array}{l}\mathrm{CH}_{3} \\
\mathrm{CH}_{3}\end{array}>\mathrm{N} \cdot \mathrm{CH}_{2} \cdot \mathrm{CH}_{2} \cdot \mathrm{CH}_{2} \cdot \mathrm{NH}$ & $134 \sim 5$ & $\begin{array}{l}217(27,600) \\
280(3,500)\end{array}$ & $\begin{array}{l}1580 \\
1534\end{array}$ & $F(75)$ \\
\hline $\mathrm{CCl}_{3}$ & $\mathrm{C}_{6} \mathrm{H}_{5} \cdot \mathrm{CH}_{2} \cdot \mathrm{NH}$ & $163 \sim 5$ & $\begin{array}{l}218(27,400) \\
282(3,000)\end{array}$ & $\begin{array}{l}1590 \\
1530\end{array}$ & $F(87)$ \\
\hline $\mathrm{CCl}_{3}$ & & $149 \sim 50$ & $\begin{array}{l}231(22,700) \\
290(3,400)\end{array}$ & $\begin{array}{l}1578 \\
1550 \\
1510\end{array}$ & $F(83)$ \\
\hline $\mathrm{CCl}_{3}$ & O_N & $186 \sim 8$ & $\begin{array}{l}230(21,500) \\
290(3,200)\end{array}$ & $\begin{array}{l}1598 \\
1545 \\
1516\end{array}$ & $F(85)$ \\
\hline $\mathrm{CCl}_{3}$ & W & $65 \sim 7$ & $\begin{array}{l}230(10,400) \\
288(2,500)\end{array}$ & $\begin{array}{l}1580 \\
1562 \\
1528\end{array}$ & $F(60)$ \\
\hline $\mathrm{CCl}_{8}$ & $\begin{array}{l}\mathrm{CH}_{3} \\
\mathrm{CH}_{3}\end{array}>\mathrm{N}$ & $170 \sim 1$ & $\begin{array}{l}216(20,600) \\
285(2,700)\end{array}$ & $\begin{array}{l}1580 \\
1515\end{array}$ & $\begin{array}{l}F(56) \\
G(50)\end{array}$ \\
\hline $\mathrm{CH}_{8}$ & $n-\mathrm{C}_{4} \mathrm{H}_{9} \mathrm{NH}$ & $80 \sim 2$ & $\begin{array}{l}220(17,800) \\
260(3,500)\end{array}$ & $\begin{array}{l}1565 \\
1500\end{array}$ & $\begin{array}{l}\mathrm{G}(0) \\
\mathrm{H}(69)\end{array}$ \\
\hline
\end{tabular}




\begin{tabular}{|c|c|c|c|c|c|}
\hline $\mathrm{R}$ & $\mathrm{R}_{1}$ & $\underset{\left({ }^{\circ} \mathrm{C}\right)}{\mathrm{Mp} .}$ & $\frac{\text { U.V. }}{\lambda_{\max }^{\mathrm{CH}_{3} \mathrm{OH}} \operatorname{m} \mu(\varepsilon)}$ & $\begin{array}{l}\text { I.R.*2) } \\
\left(\mathrm{cm}^{-1}\right)\end{array}$ & (方 洼)\% \\
\hline $\mathrm{CH}_{3}$ & iso- $\mathrm{C}_{4} \mathrm{H}_{9} \mathrm{NH}$ & $130 \sim 1$ & $\begin{array}{l}221(16,400) \\
260(3,100)\end{array}$ & $\begin{array}{l}1552 \\
1496\end{array}$ & $\begin{array}{l}\mathrm{G}(0) \\
\mathrm{H}(65)\end{array}$ \\
\hline
\end{tabular}

表 1 脚注

* 元素分析値は，計算值と一致した。

*1) 末補正

*2) $s$-トリアシシン核特性吸收

*3) s. singet, d. doublet, t. triplet, q. quartet, qi. quintet, h. heptet, m. multiplet, br. broad : $-\mathrm{R}$. $\boldsymbol{s}$-トリアシン核置換; $-\mathrm{N}, \mathrm{N}-$ 㯰換 :

ca, circa

*4) O. Weiberg, Ger. P. 1,117,131(1961); BP 948, 175(1964)

*5) E. Knüsli, K. Rüfenacht, H. Gysin, Ger. $P$ 1, 107, 448(1961); USP 3, 086, 855 (1963)

注）先報に報告した対称型 $s$ ートリアジン(3) も，二の方法によって得られる。 $\mathrm{R}_{1}=\mathrm{R}_{2}=\mathrm{C}_{2} \mathrm{H}_{5} \mathrm{NH}, \mathrm{R}=\mathrm{CH}_{3}\left(\mathrm{Mp}, 165 \sim 7^{\circ} \mathrm{C}\right.$; 収率 $88 \%$, 方法 B);

$\mathrm{R}_{1}=\mathrm{R}_{2}=n-\mathrm{C}_{4} \mathrm{H}_{9} \mathrm{NH}, \mathrm{R}=\mathrm{CCl}_{3}\left(\mathrm{Mp}, 92 \sim 3^{\circ} \mathrm{C}\right.$; 収率 $85 \%$, 方法 $\left.\mathrm{C}\right) ; \mathrm{R}_{1}=\mathrm{R}_{2}=n-\mathrm{C}_{3} \mathrm{H}_{7} \mathrm{NH}, \mathrm{R}=n-\mathrm{C}_{3} \mathrm{H}_{7}\left(\mathrm{Mp}, 129 \sim 30^{\circ} \mathrm{C}\right.$; 收率 $84 \%$, 方法 $\mathrm{A}$ )

表 2 脚注

* 元素分析値は，計算值と一致した。

*1) 未補正

*2) sートリアシンン核特性吸収

*3) A. Weddige, J. prakt. Chem. (2) 33 76 90 (1886); Chem. Zentr. 1886308.

13, 900), $282(1,640)$ から, $232(10,500), 264(3,750)$ に移動が見られた。

以上の結果から，(2b) と（4a）とから（3b）の生成さ れたここが証明された。表 1 に合成された 2-アルキル -4, 6-非対 称ビス（アルキルアミノ)-s-トリアジンク)を 一覧する。

次に，2-アルキル-4-アルキルアミノ-6-アミノ-s-下 リアジン（式 (3) で, $\mathrm{R}_{1}=\mathrm{R}_{2}=\mathrm{H}$ ) の合成, 生成について 述べる。

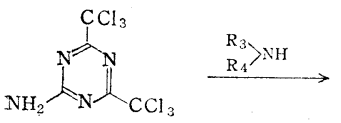

(2c)

$y^{2}$<smiles>Cc1nc(N)nc(C(Cl)(Cl)Cl)n1</smiles>

(2e)

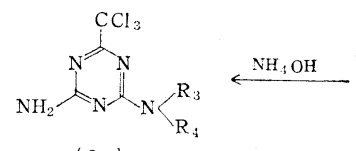

(3c)<smiles>[R1]N([R4])c1nc(C)nc(N)n1</smiles>

(3d)<smiles>[R1]N([R1])c1nc(C(Cl)(Cl)Cl)nc(C(Cl)(Cl)Cl)n1</smiles>

(2d)<smiles>[R1]N([R1])c1nc(C)nc(C(Cl)(Cl)Cl)n1</smiles>

(2f)
$\mathrm{NH}_{4} \mathrm{OH}$ の塩基性の相異が主な原因であろらと思われ

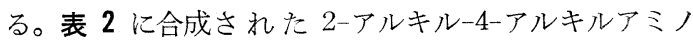
-6-アミノ-s-トリアジンを示す。

\section{実験*2)}

〔原料】2-アルキル-4-(置換) アミノー6-トリクロルメ チル-s-トリアジン類は, 第 3 報1)の方法, Weddige ${ }^{8}$ お よび Grundmann" ${ }^{92}$ らの方法により合成した。アミン類 は，東京化成または和光純薬の試薬 1 級および特級品で ある。

〔分析機器】 U.V. は Perkin-Elmer Model 202 を, I.R. は JASCO IR-S を，N.M.R.はVarian A-60を，Mass は日立 RMU-6C スペクトロメーター を使用して測定した。

〔分離・精製】反応後, 過剩のアミ ン, 溶媒, 生成した $\mathrm{CHCl}_{3}$ を減圧留去 する。生成物が固体のものは水洗して アルコールなどから再結晶する。液体 のものは蒸留により, また蒸留により分解されるものに ついてはカラムクロマトグラフィーにより精製された。

1. 2-メチル-4-エチルアミノ-6-(n-プロピルアミ ノ)-s-トリアジンの合成（方法 $\mathbf{A}$ ） 2-メチル-4-エ チルアミノ-6-トリクロルメチルーงートリアジン $25.6 \mathrm{~g}$ (0.1 モル) に, 水冷下で $n$-プロピルアミン $17.5 \mathrm{~g}(0.3$ モル）を加え, 均一になるまで振とらした後, 室温で 3 時間かくはんする。過剩のアミンおよび生成したクロロ ホルムを減圧留去すると, 融点 $143 \sim 6^{\circ} \mathrm{C}$ の粗 2-メチル -4-エチルアミノ-6-(n-プロピルアミノ)-s-トリアジ $\frac{\text { ン } 18 \mathrm{~g}(92 \%) \text { をうる。エタノールから再結晶すると, }}{\text { *2) まぎらわしいので, } s \text {-トリアシンの命名は一応反応の位置を } 6 \text { 位の }}$ $\mathrm{CCl}_{3}$ 基と決め, 万国法によらなかった。 
融点は $148 \sim 9^{\circ} \mathrm{C}$ に上る。

分析值 C $55.49 \% \mathrm{H} 8.90 \%, \mathrm{~N} 35.72 \%, \mathrm{C}_{9} \mathrm{H}_{17} \mathrm{~N}_{5}$ としての計算值 C $55.35 \%, \mathrm{H} 8.78 \%, \mathrm{~N} 35.87 \%$

I.R., N.M.R. は表 1 に示したとうり，生成物の構造 を支持する。Mass スペクトル：分子量ピーク $\left(\mathrm{M}^{+}\right) \mathrm{m} / \mathrm{e}$ 195。主なるフラグメントピークとして, m/e $180\left(\mathrm{M}^{+}-\right.$ $\left.\mathrm{CH}_{3}\right), 166\left(\mathrm{M}^{+}-\mathrm{C}_{2} \mathrm{H}_{5}\right), 152\left(\mathrm{M}^{+}-\mathrm{C}_{3} \mathrm{H}_{7}\right), 151\left(\mathrm{M}^{+}-\mathrm{C}_{2}-\right.$ $\left.\mathrm{H}_{5} \mathrm{NH}\right), 123,84\left(\mathrm{C}_{3} \mathrm{H}_{7} \mathrm{NH} \cdot \mathrm{CN}\right), 70\left(\mathrm{C}_{2} \mathrm{H}_{5} \cdot \mathrm{NH} \cdot \mathrm{CN}\right)$ お よび $43\left(\mathrm{C}_{3} \mathrm{H}_{7}^{+}\right)$が見られる。

\section{2-メチル-4-(iso-ブチルアミノ)-6-エチルアミ} ノ-s-トリアジンの合成（方法 B'） 2-メチル-4-(isoブチルアミノ)-6-トリクロル-S-メチルトリアジン 14. $2 \mathrm{~g}(0.05$ モル) に, 水冷下で $70 \%$ エチルアミン我溶 液 $9.8 \mathrm{~g}$ (0.15 モル) を加え, 均一になるまで振とうを 続ける。室温にて 3 時間放置後, 分離・精製を行なう。 粗結晶 $9.5 \mathrm{~g}(96 \%)$ 。融点 $158 \sim 9^{\circ} \mathrm{C}$ (エタノール)。

分析值 C $57.54 \%, \mathrm{H} 9.31 \%, \mathrm{~N} 33.65 \%, \mathrm{C}_{10} \mathrm{H}_{19}$ $\mathrm{N}_{5}$ としての計算值 C $57.38 \%, \mathrm{H} \mathrm{9.15 \% ,} \mathrm{N} 33.47 \%$

U.V., I.R., N.M.R. も表 1 に示したように推定構造 学満足する。

3. 2-メチル-4-アリル アミノ-6-エチルアミノ-s-ト リアジンの合成（方法 C) 2-メチルー4-エチルアミ ノー6-トリクロルメチル-s-トリアジン $25.6 \mathrm{~g}(0.1$ モル $)$ を $50 \mathrm{ml}$ の DMF に溶解し，これにアリルアミン $17.1 \mathrm{~g}$ (0.3 モル) を徐々に滴下反応せしめた後， 3 時間室温 でかくは九する。次いで水水 $1 l$ を入れたビーカーに反 応混合物を注加すると, 結晶が析出する。エタノールよ り再結晶する。融点 $160 \sim 2{ }^{\circ} \mathrm{C}$ 。収量 $16.6 \mathrm{~g}$ (86\%)。 分析值 C $56.12 \%, \mathrm{H} 7.98 \%, \mathrm{~N} 36.36 \%, \mathrm{C}_{9} \mathrm{H}_{15} \mathrm{~N}_{5}$ としての計算值 C $55.93 \%, \mathrm{H} 7.82 \%, \mathrm{~N} 36.24 \%$ 。

U.V., I.R., N.M.R. は推定構造とよく一致する。(表 1 参照)

\section{2-メチル-4-(n-ドデシルアミノ)-6-エチル アミ} ノーs-トリアジンの合成（方法 D) 2-メチル-4-工 チルアミノー6-トリクロルメチル-s-トリアジン $25.6 \mathrm{~g}$ (0.1 モル) を， $n$-ドデシルアミン $27.8 \mathrm{~g}$ (0.15モル) と $\mathrm{Na} 1.2 \mathrm{~g}$ を溶解したメタノール $(150 \mathrm{ml})$ 溶液中に, 少しずっ加える。1 時間, 室温でかくはんした後，メタ ノールを留去する。残留物を水洗した後, メタノールよ り再結晶する。融点 $108 \sim 9^{\circ} \mathrm{C}$ 。収量 $25.8 \mathrm{~g}(80 \%)$ 。

分析值 C $67.00 \%, \mathrm{H} 10.82 \%, \mathrm{~N} 21.84 \%, \mathrm{C}_{18} \mathrm{H}_{35}$ $\mathrm{N}_{5}$ としての計算值 C $67.24 \%, \mathrm{H} 10.97 \%, \mathrm{~N} 21$. $79 \%$ 。 $\left(\mathrm{C}_{2} \mathrm{H}_{5}\right)_{3} \mathrm{~N}$ も触媒として有効である。たとえば， 実験例 3 において, $\left(\mathrm{C}_{2} \mathrm{H}_{5}\right)_{3} \mathrm{~N} 1 \mathrm{~g}(0.01$ モル) を添加し て，1時間かくはんし反応を行なうと，2-メチルー4-ア
リルアミノー6-エチルアミノーงートリアジンが 93\% 収率 で得られる（方法 $\mathbf{E ) ~}$

5. 2-トリクロルメチル-4-アミノ-6-(iso-プロピル アミノーs-トリアジンの合成（方法 F） 2-アミ， -4, 6-ビス (トリクロルメチル)-s-トリアジン $33 \mathrm{~g}(0.1$ モル）とiso-プロピルアミン $18 \mathrm{~g}(0.3$ モル $)$ を, DMF $(75 \mathrm{ml})$ 中で方法Cにしたがって反応せしめると, 表記 化合物の粗結晶 $22.5 \mathrm{~g}(88 \%)$ を得る。融点 $151 \sim 2^{\circ} \mathrm{C}$, (エノタール)。

分析值 C $32.87 \%, \mathrm{H} 4.08 \%, \mathrm{~N} 21.80 \%, \mathrm{Cl} 41$. $55 \%$ 。 $\mathrm{C}_{7} \mathrm{H}_{10} \mathrm{~N}_{4} \mathrm{Cl}_{3}$ としての計算值 C $32.77 \%, \mathrm{H} 3$. $93 \%, \mathrm{~N} 21.84 \%, \mathrm{Cl} 41.46 \%$ 。

I.R. $1568 \mathrm{~cm}^{-1}, 1535 \mathrm{~cm}^{-1}$ ( $s$-トリアジン核特性吸収): この物質は，2-(iso-プロピルアミノ)-4,6-ビス（ト リクロルメチル) - -トリアジン (0.1 モル) と 28\% $\mathrm{NH}_{4} \mathrm{OH}(50 \mathrm{ml})$ を上記の方法で $\mathrm{DMF}$ 中にて反応せし めても得られる。収量 $20 \mathrm{~g}(78 \%)$ 。(方法 $\mathbf{G}$ )

6. 2-メチル-4-アミノ-6-(n-ブチルアミノ)-s-トリ アジンの合成（方法H） 2-アミノー4-メチルー6-トリ クロルメチルーートリアジン $11.4 \mathrm{~g}(0.05$ モル) と $n$ ブチルアミン $22 \mathrm{~g}$ (0.3 モル) を $\mathrm{DMF}(75 \mathrm{ml})$ に加え,. 10時間還流させる。冷後, 方法 C と同様に処理すると表 題化合物の粗結晶 $11.5 \mathrm{~g}(69 \%)$ を得る。融点 $80 \sim 2^{\circ} \mathrm{C}$ (エタノール)。

分析值 C $52.92 \%, \mathrm{H} 8.48 \%, \mathrm{~N} 38.56 \%, \mathrm{C}_{8} \mathrm{H}_{15}$ $\mathrm{N}_{5}$ としての計算值 C $53.01 \%, \mathrm{H} 8.34 \%, \mathrm{~N} \mathrm{38.64 \%}$

2-(n-ブチルアミノ)-4-メチル-6-トリクロルメチル -s-トリアジンは, DMF 中, 温度 $100 \sim 130^{\circ} \mathrm{C}$ で $\mathrm{NH}_{3}$ ガスを導入しても，また $28 \% \mathrm{NH}_{4} \mathrm{OH}$ と封管中で反応 にかけても，表題化合物に移行しなかった。

終りに, 本研究の分析全般にわたる解析に協力してい ただいた三菱化成 K.K. 中央研究所滝川幸雄・井橋義夫 両氏に感謝の意を表します。

\section{文献}

1）若林攻, 角田勝, 鈴木泰, 有合化 27868 (1969)

2) E. Knüsli, K. Rüfenacht, H. Gysin, Ger. $P$. 1, 107, 448 (1961); USP 3, 086, 855 (1963)

3) K.H. Slotta, R. Tschesche, Chem. Ber. 621390 (1929)

4) H. Gysin, E. Knüsli, Swiss. P. 337, 019 (1959)

5) R. Hirt, H. Nidecher, R. Berchtold, Helv. Chim. Acta 331365 (1950)

6) 奥津正彦，林竜三，若林攻，鈴木泰，日特願 昭 42-52,006 (1967)

7) 松井和夫, 若林攻, 角田勝, 鈴木泰, 津田正孝, 中沢誠, 日特願 昭 42-79,006 (1967)

8) A. Weddige, J. prakt. Chem. (2) 3376 (1886); Chem. Zentr. 1886308

9) C. Grundmann, A. Kreutzberger, USP 2, 858, 310 (1958) 